\title{
Breast-milk production and energy exchange in human lactation
}

\author{
BY R. M. ENGLISH \\ Nutrition Section, Commonwealth Department of Health, Woden, Australian Capital \\ Territory 2606, Australia
}

(Received 22 June 1984 - Accepted 29 November 1984)

1. The milk production of one mother was determined post-partum for a period of 13 weeks, during which time breast milk was her infant's only source of food energy. The weight changes of both the mother and the male infant were recorded during this period.

2. The food intake and activity pattern of the mother were also recorded for 4-week periods: at $2,6,10$ weeks after birth and 2 weeks after the cessation of lactation, which was maintained for a period of 27 weeks.

3. The infant regained his birth weight of $3310 \mathrm{~g}$ on the 14 th day of life. His weight gain for the duration of the study, which averaged $233 \mathrm{~g} /$ week, was considered satisfactory.

4. The daily milk production increased gradually from an average of $241 \mathrm{~g}$ during the 1 st week post-partum to $995 \mathrm{~g}$ during the 12 th week. The infant's maximum milk intake and hence food energy intake per kg body-weight was (range) 198-204 g milk and 550-560 kJ/kg respectively during the 3rd to the 7 th week, followed by a gradual decrease from the 8 th to the 13 th week after birth.

5. The estimated efficiency of energy coversion for breast-milk production was consistent with other values reported in the literature.

Adequacy of lactation is dependent on the volume and composition of breast milk. Reliable information, however, on the volume of milk production is scanty, due to technical difficulties in obtaining representative $24 \mathrm{~h}$ samples for prolonged periods of time. In particular, there is a dearth of information in the literature concerning the longitudinal measurement of the milk production of breast-feeding mothers living under normal social and dietetic conditions. Beach et al. (1941) reported a mean intake by two infants of 0.792 litres $/ 24 \mathrm{~h}$ for a 5-month period from birth and Chilver \& McCance (1967) recorded a mean daily milk intake of 0.818 litres during the first 21 weeks of life.

A number of cross-sectional studies have determined breast-milk production at different stages of lactation (Wallgren, 1944; Lonnerdal et al. 1976; Picciano et al. 1981; Rattigan et al. 1981; Whitehead \& Paul, 1981a; Hofvander et al. 1982). The maximal mean daily milk production reported in these studies was approximately 0.850 litres, except Rattigan et al, (1981) observed a mean milk production of 1.238 litres at 3 months of lactation. The present paper reports the milk production of a mother post-partum for a period of 13 weeks and considers the observed milk production in relation to the weight changes of mother and infant and the food intake and activity of the mother. For the present study, it is accepted that the breast-milk production of the mother is equivalent to the breast-milk intake of the infant.

\section{EXPERIMENTAL}

The subjects were a healthy multipara (CD), aged 28.5 years, and her male infant (FJD) who weighed $3310 \mathrm{~g}$ at birth. From the 2 nd day post-partum, breast-milk production was measured at every feed for a period of 13 weeks. During this time the infant was fully breast-fed. To measure milk production, the mother weighed FJD clothed, before and after every feed, on a Wedderburn baby balance scale, weighing up to $15 \mathrm{~kg}$ in $5 \mathrm{~g}$ gradations. To determine weight gain during the study period, FJD was weighed daily, without clothes, before his second feeding. 
A $7 \mathrm{~d}$ dietary record was completed by the mother during weeks 2,6 and 10 of the study and 4 weeks after lactation of 27 weeks duration was terminated. During each of these weeks, the mother's activity pattern was recorded. Food intake was measured, using standard measuring cups and spoons. The average daily intakes of food energy and protein for each of the 4 weeks of food recording were estimated with reference to the Tables of Composition of Australian Foods (Thomas \& Corden, 1970). The mother's body-weight was measured weekly on an Avery balance scale (Model 3559AAE) with $5 \mathrm{~g}$ gradations.

The nutrient composition of breast-milk production was calculated using the following values $(\mathrm{g} / \mathrm{kg}$ breast milk) (Blanc, 1981): colostrum (1-5 d): 41 protein, 29 fat, 55 carbohydrate, $2650 \mathrm{~kJ}$; transitional (6-10 d): 16 protein, 35 fat, 66 carbohydrate, $2620 \mathrm{~kJ}$; mature (day $11+$ ): 9 protein, 40 fat, 70 carbohydrate, $2750 \mathrm{~kJ}$.

During the 16 weeks of lactation, CD's milk was analysed for protein, fat and carbohydrate content. The sample for analysis was collected by complete manual expression of both breasts immediately before the time of the second feeding of the day ( 10.00 hours). Total nitrogen in the milk was determined by the Kjeldahl method and protein content was calculated using a conversion factor of 6.25 . Lactose content was estimated by a modification of the orcinol method (Graham et al. 1970). To determine fat content, total esterified fatty acid content was analysed.

\section{RESULTS}

Table 1 shows the weight changes of infant and mother, the mean daily milk intake of infant from 1 to 13 weeks after birth and the mean daily energy and protein intake of the mother during 2, 4 and 10 weeks after birth and the 2 nd week after cessation of lactation.

\section{Weight gain of infant}

FJD did not regain his birth weight of $3310 \mathrm{~g}$ until 2 weeks of age. From 1 to 13 weeks of life, the infant gained weight steadily, with an average weekly increase of $233 \mathrm{~g}$. Satisfactory weight gain of an infant over a reasonable period of time, which would include 13 weeks, is considered an acceptable index of adequacy of breast-feeding. The weight gain of FJD relative to the 25th percentile line of the National Centre for Health Statistics (NCHS) reference (Hamil, 1977), as illustrated in Fig. 1, was judged as adequate. It was considered, therefore, that maternal milk production during the period of the present study was adequate.

\section{Breast-milk production}

The mean daily milk intake of FJD ranged from 241 (SE 66) $\mathrm{g}$ in the 1st week of lactation to a maximum value of 995 (SE 28) $\mathrm{g}$ in the 12 th week (Table 1). There was a consistent pattern of increase in daily milk intake during this period. The mean daily intake of the infant on a per $\mathrm{kg}$ body-weight basis is also given in Table 1. Maximum intake per $\mathrm{kg}$ body-weight was observed for 3 to 7 weeks (range $206-210 \mathrm{~g} / \mathrm{kg}$ ) with a subsequent gradual decrease to the 13 th week of lactation.

\section{Diurnal variation in milk intake}

The diurnal variation in milk intake from the 6 th to the 13 th week post-partum is reported in Table 2. From the beginning of the 6th week of lactation, five feedings were provided regularly each day at approximately $06.00,10.00,14.00,17.30$ and 21.00 hours. There was a clear pattern of diurnal variation in milk intake. Consistent with other results published in the literature (Hytten, 1954), the mean (with SE) milk intake was maximal at the early-morning feeding 266 (SE 9) g and then decreased during the day to 133 (SE 5) g at the 
Table 1. Body-weight and milk intake of a male infant from birth to 13 weeks of age and body-weight and energy and protein intakes of the mother during weeks 1-13 of lactation

(Mean values with their standard errors, ranges given in parentheses)

\begin{tabular}{|c|c|c|c|c|c|c|c|}
\hline \multirow[b]{4}{*}{ Week } & \multicolumn{3}{|c|}{ Baby } & \multicolumn{4}{|c|}{ Mother } \\
\hline & \multirow{3}{*}{$\begin{array}{c}\text { Wt at } \\
\text { end of week } \\
(\mathrm{kg})\end{array}$} & \multirow{2}{*}{$\begin{array}{l}\text { Daily milk } \\
\text { intake }(\mathrm{g})\end{array}$} & \multirow{3}{*}{$\begin{array}{l}\text { Mean daily milk } \\
\text { intake }(\mathrm{g} / \mathrm{kg} \\
\text { body-wt) }\end{array}$} & \multirow{3}{*}{$\begin{array}{r}\mathrm{Wt} \\
(\mathrm{kg})\end{array}$} & \multicolumn{3}{|c|}{ Dietary intake $(/ d)$} \\
\hline & & & & & Energy (kJ) & \multicolumn{2}{|l|}{ Protein (g) } \\
\hline & & Mean & & & Mean & Mean & SE \\
\hline Birth & $3 \cdot 310$ & - & - & - & - & - & \\
\hline 1 & $3 \cdot 104$ & $\begin{array}{cc}241 & 66 \\
(45-430)\end{array}$ & $\begin{array}{c}75 \\
(14-139)\end{array}$ & $50 \cdot 35$ & - & - & \\
\hline 2 & $3 \cdot 315$ & $\begin{array}{lr}520 & 52 \\
(345-690)\end{array}$ & $\begin{array}{c}163 \\
(104-208)\end{array}$ & $48 \cdot 28$ & $\begin{array}{lr}9110 & 829 \\
(6942-12089)\end{array}$ & $\begin{array}{lr}95 & 13 \\
(63-151)\end{array}$ & \\
\hline 3 & $3 \cdot 570$ & $\begin{array}{lr}712 & 30 \\
(590-825)\end{array}$ & $\begin{array}{c}210 \\
(165-231)\end{array}$ & $49 \cdot 87$ & - & - & \\
\hline 4 & $3 \cdot 780$ & $\begin{array}{lr}758 & 25 \\
(645-855)\end{array}$ & $\begin{array}{c}207 \\
(170-226)\end{array}$ & $48 \cdot 02$ & - & - & \\
\hline 5 & 4.075 & $\begin{array}{lr}804 & 20 \\
(695-840)\end{array}$ & $\begin{array}{c}206 \\
(171-206)\end{array}$ & $49 \cdot 14$ & $\begin{array}{lr}9678 & 998 \\
(6786-13738)\end{array}$ & $\begin{array}{lr}76 & 6 \\
(54-104)\end{array}$ & \\
\hline 6 & $4 \cdot 450$ & $\begin{array}{lr}871 & 55 \\
(670-1140)\end{array}$ & $\begin{array}{c}208 \\
(151-256)\end{array}$ & $47 \cdot 42$ & - & - & \\
\hline 7 & $4 \cdot 665$ & $\begin{array}{cr}941 & 20 \\
(870-1010)\end{array}$ & $\begin{array}{c}209 \\
(186-217)\end{array}$ & $48 \cdot 17$ & - & - & \\
\hline 8 & 4.950 & $\begin{array}{lr}880 & 29 \\
(770-950)\end{array}$ & $\begin{array}{c}183 \\
(156-192)\end{array}$ & $48 \cdot 43$ & - & - & \\
\hline 9 & $5 \cdot 160$ & $\begin{array}{lr}928 & 32 \\
(820-1020)\end{array}$ & $\begin{array}{c}186 \\
(159-198)\end{array}$ & $48 \cdot 00$ & - & - & \\
\hline 10 & $5 \cdot 250$ & $\begin{array}{lr}972 & 23 \\
(855-1030)\end{array}$ & $\begin{array}{c}187 \\
(163-196)\end{array}$ & $47 \cdot 62$ & $\begin{array}{c}8892-772 \\
(5563-10485)\end{array}$ & $\begin{array}{lr}73 & 5 \\
(55-94)\end{array}$ & \\
\hline 11 & $5 \cdot 620$ & $\begin{array}{lr}937 & 17 \\
(870-990)\end{array}$ & $\begin{array}{c}172 \\
(155-176)\end{array}$ & $48 \cdot 86$ & - & - & \\
\hline 12 & $5 \cdot 635$ & $\begin{array}{rr}995 & 28 \\
(910-1130)\end{array}$ & $\begin{array}{c}176 \\
(161-201)\end{array}$ & $47 \cdot 70$ & - & - & \\
\hline 13 & $5 \cdot 900$ & $\begin{array}{lr}979 & 34 \\
(810-1070)\end{array}$ & $\begin{array}{c}169 \\
(137-181)\end{array}$ & 47.31 & - & - & \\
\hline $\begin{array}{l}\text { Week } 2 \text { after } \\
\text { cessation of } \\
\text { lactation }\end{array}$ & - & - & - & - & $\begin{array}{lr}7400 & 828 \\
(5597-11335)\end{array}$ & $\begin{array}{lr}68 & 7 \\
(47-102)\end{array}$ & \\
\hline
\end{tabular}

late-evening feeding. An analysis of variance revealed a highly significant linear decrease in milk consumption during the day $(P<0.001)$.

It is agreed that the volume of milk obtained at a feeding is due to a combination of two factors: length of time since last feeding and capacity of the breasts.

\section{Nutrient intake of infant}

To estimate the nutrient intake of FJD during the period of the study, it was assumed that all milk taken during the first $5 \mathrm{~d}$ of life was colostrum, the milk taken from 6 to $10 \mathrm{~d}$ was transitional and then subsequent milk was mature. Using the reference values of Blanc (1981), the mean daily intakes of protein, fat, carbohydrate and food energy of the infant were calculated for each week of the study. These nutrient intakes are given in Table 3, together with the infant's mean daily protein and energy intakes $/ \mathrm{kg}$ body-weight. From 3 to 10 weeks after birth, the energy intake of the infant was in excess of, or approximated to, 


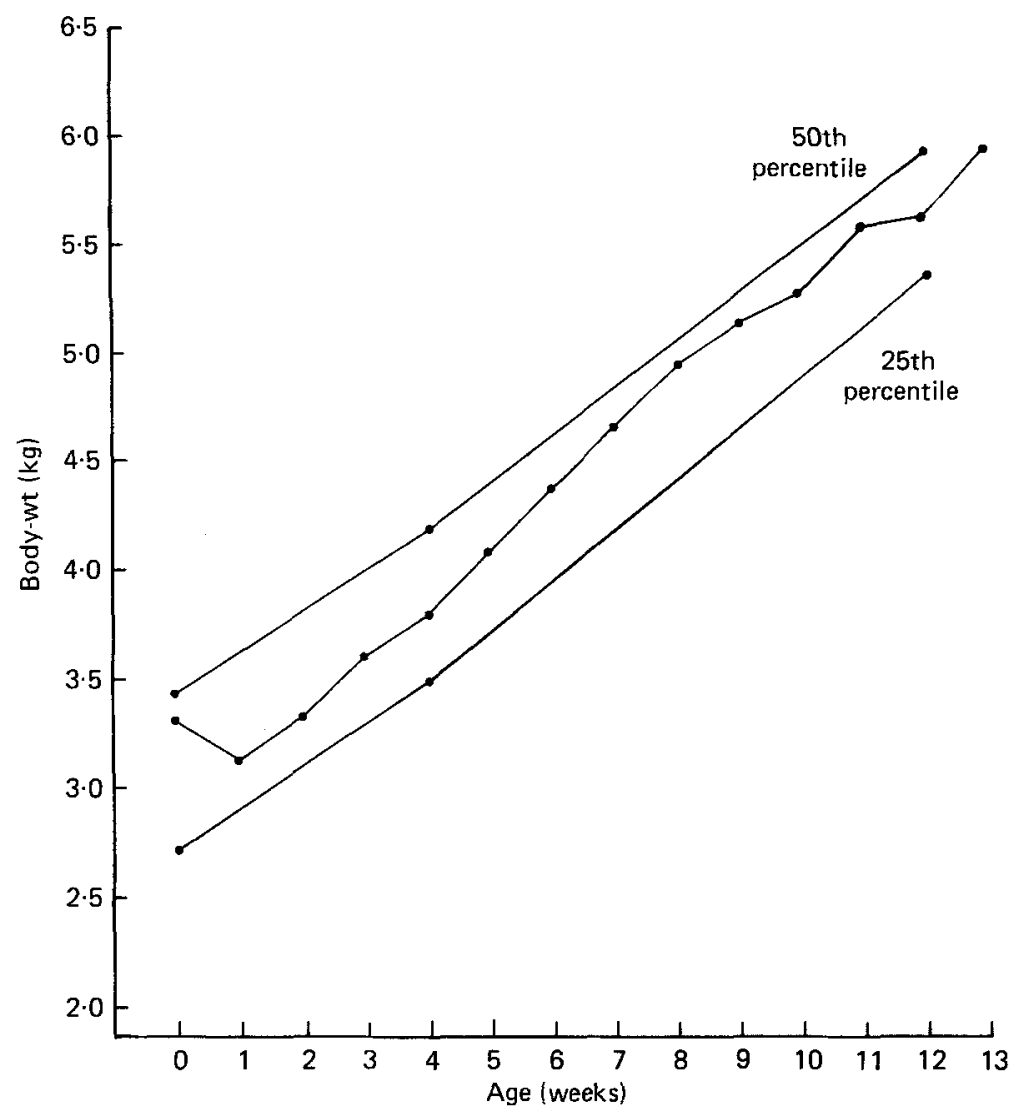

Fig. 1. Comparison of the weight gain of a male infant from 1 to 13 weeks of age with values from the National Centre for Health Statistics (Hamil, 1977).

Table 2. Diurnal variation* in milk intake by a male infant during 6-13 weeks of age

\begin{tabular}{|c|c|c|c|c|c|c|c|c|c|c|}
\hline \multirow[b]{2}{*}{$\begin{array}{l}\text { Week no... } \\
\text { Approximate } \\
\text { feed time } \\
\text { (hours) }\end{array}$} & \multicolumn{9}{|c|}{ Milk intake ( $\mathrm{g} /$ per feed) } & \multirow[b]{2}{*}{ SE } \\
\hline & 6 & 7 & 8 & 9 & 10 & 11 & 12 & 13 & Mean & \\
\hline 06.00 & 220 & 250 & 270 & 260 & 280 & 285 & 300 & 266 & 266 & 9 \\
\hline 10.00 & 180 & 165 & 165 & 215 & 170 & 160 & 235 & 205 & 187 & 10 \\
\hline 14.00 & 150 & 235 & 155 & 165 & 190 & 195 & 180 & 210 & 185 & 10 \\
\hline 17.30 & 165 & 145 & 170 & 160 & 180 & 150 & 155 & 150 & 159 & 4 \\
\hline 21.00 & 155 & 130 & 115 & 130 & 150 & 125 & 115 & 145 & 133 & 5 \\
\hline
\end{tabular}

* An analysis of variance revealed a highly significant linear decrease in milk yield during the day. 
Table 3. Mean daily nutrient intake of a male infant from 1 to 13 weeks of age

\begin{tabular}{|c|c|c|c|c|c|c|}
\hline Week & $\begin{array}{c}\text { Energy } \\
(\mathrm{kJ})\end{array}$ & $\begin{array}{l}\text { Energy }(\mathrm{kJ} / \mathrm{kg} \\
\text { body-wt) }\end{array}$ & $\begin{array}{l}\text { Protein } \\
\text { (g) }\end{array}$ & $\begin{array}{l}\text { Protein }(\mathrm{g} / \mathrm{kg} \\
\text { body-wt) }\end{array}$ & $\begin{array}{l}\text { Fat } \\
(\mathrm{g})\end{array}$ & $\begin{array}{c}\text { Carbohydrate } \\
\text { (g) }\end{array}$ \\
\hline 1 & 617 & 192 & 6.7 & $2 \cdot 1$ & $7 \cdot 5$ & $14 \cdot 1$ \\
\hline 2 & 1371 & 429 & 5.7 & 1.8 & $19 \cdot 4$ & $34 \cdot 8$ \\
\hline 3 & 1899 & 560 & $6 \cdot 2$ & 1.8 & $27 \cdot 6$ & $48 \cdot 3$ \\
\hline 4 & 2038 & 557 & 6.7 & 1.8 & $29 \cdot 6$ & 51.8 \\
\hline 5 & 2147 & 550 & $7 \cdot 0$ & 1.8 & 31.2 & $54 \cdot 6$ \\
\hline 6 & 2313 & 552 & 7.6 & 1.8 & 33.6 & 58.8 \\
\hline 7 & 2505 & 557 & $8 \cdot 2$ & 1.8 & $36 \cdot 4$ & $63 \cdot 7$ \\
\hline 8 & 2340 & 486 & $7 \cdot 7$ & 1.6 & 34.0 & $59 \cdot 5$ \\
\hline 9 & 2477 & 496 & $8 \cdot 1$ & 1.6 & 36.0 & 63.0 \\
\hline 10 & 2588 & 498 & 8.5 & 1.6 & $37 \cdot 6$ & 65.8 \\
\hline 11 & 2505 & 460 & $8 \cdot 2$ & 1.5 & $36 \cdot 4$ & 63.7 \\
\hline 12 & 2669 & 472 & $8 \cdot 7$ & 1.5 & $38 \cdot 8$ & 67.9 \\
\hline 13 & 2616 & 451 & 8.6 & 1.5 & 38.0 & $66 \cdot 5$ \\
\hline \multicolumn{2}{|c|}{$\begin{array}{l}\text { US recommended } \\
\text { dietary allowance* }\end{array}$} & 480 & & $2 \cdot 2$ & - & \\
\hline
\end{tabular}

* Food and Nutrition Board (1980).

Table 4. Nutrient composition of mother's mature milk $(/ \mathrm{kg})$

\begin{tabular}{ccccc}
\hline \hline & $\begin{array}{c}\text { Energy* } \\
(\mathrm{kJ})\end{array}$ & $\begin{array}{c}\text { Protein } \\
(\mathrm{g})\end{array}$ & $\begin{array}{c}\text { Fat } \\
(\mathrm{g})\end{array}$ & $\begin{array}{c}\text { Carbohydrate } \\
(\mathrm{g})\end{array}$ \\
\hline $\begin{array}{c}\text { Mature milk at } \\
\text { 16th week of lactation }\end{array}$ & 261 & 9 & 34 & 75 \\
\hline
\end{tabular}

* Calculated using the following energy conversion factors: protein $\times 17$, fat $\times 37$ and carbohydrate $\times 16$.

the (US) Food and Nutrition Board (1980) allowance of $480 \mathrm{~kJ} / \mathrm{kg}$ body-weight. In weeks 11-13, energy intake $/ \mathrm{kg}$ body-weight decreased to a level marginally below the allowance. The infant's protein intake only provided $68-80 \%$ of the allowance of $2 \cdot 2 \mathrm{~g} / \mathrm{kg}$ body-weight.

Table 4 details the energy, protein, fat and carbohydrate composition of the mother's mature milk at the 16 th week of lactation. These values are of the same order as those used as the reference for mature milk to calculate the nutrient intake of the infant.

\section{Maternal weight change}

During the study, a gradual decrease in maternal weight was observed from $50.35 \mathrm{~kg}$ at 1 week post-partum to $47.31 \mathrm{~kg}$ at the end of the study (Table 1). Weight loss over this period of lactation was $3.04 \mathrm{~kg}$ (equivalent to a food energy value of $82100 \mathrm{~kJ}$ on the assumption that $1 \mathrm{~kg}$ fat $=27000 \mathrm{~kJ}$ (Thomson et al. 1970)). On a daily basis, the energy equivalent of maternal weight loss was estimated as $900 \mathrm{~kJ}$.

\section{Maternal nutrient intake}

The average maternal daily intakes of food energy and protein, calculated for each of the 4 weeks in which a diet record was kept, are given in Table 1. To obtain an estimate of daily energy intake during the lactation, the values for daily energy intake calculated from the food records of weeks 2, 6 and 10 were averaged to give a mean intake of 9227 (SE 872) kJ. The Australian recommended allowance for food energy for an 18-35-year-old lactating 
reference woman weighing $58 \mathrm{~kg}$ is $10900 \mathrm{~kJ} / \mathrm{d}$ (National Health and Medical Research Council, 1979). An adjustment for the lighter body-weight of CD compared with the reference woman gives an energy allowance of $10200 \mathrm{~kJ} / \mathrm{d}$ (National Health and Medical Research Council, 1979). The mean daily energy intake 2 weeks after the cessation of lactation was 7400 (SE 820) kJ. At this time, CD's weight was stable.

\section{Maternal activity pattern}

During the periods that the food records were kept, $\mathrm{CD}$ maintained a diary detailing her various activities during each day together with the duration of each. Beside her infant, $C D$ also cared for a pre-school child. From this information, the average number of hours that $\mathrm{CD}$ spent sleeping, sitting, walking, engaged in housework, etc. were calculated. The average daily activity pattern was as follows: sleeping $8.20 \mathrm{~h}$, sitting (including breast-feeding) $6.00 \mathrm{~h}$, general household activities $6.40 \mathrm{~h}$, walking $2.00 \mathrm{~h}$.

The mother, therefore, maintained a moderate level of energy expenditure, equivalent to that of the reference woman described in the Dietary Allowances for Use in Australia (National Health and Medical Research Council, 1979).

\section{DISCUSSION}

Over recent years there has been an increasing appreciation of the mother-child dyad (the mother and her child from conception through fetal life and from birth through infancy) as a basic human unit. The lactating mother and her infant form a unified biological organism and the nutrition of both are integrated through the metabolic mechanisms of the mother. The mother provides the infant's food and fluid as milk both from the maternal diet and body fat stores laid down in pregnancy. For this reason, information on maternal weight changes, diet and activity was collected in addition to information on milk production and weight gain of the infant.

One other study reported the serial breast-milk intake and growth of a male infant (ASC) over a period of 21 weeks (Chilver \& McCance, 1967). For the first 5 weeks of life, ASC's mean daily milk intake was higher (ranging from 456 to $818 \mathrm{~g}$ ) than FJD's intake. From weeks 6-13, however, FJD's mean daily intake was higher. Infant ASC received supplementary foods after 5 weeks of age. From weeks 6 to 13, his mean daily milk intake ranged from 807 to $914 \mathrm{~g}$.

For infant FJD, maximum milk intake per $\mathrm{kg}$ body-weight was recorded from 3 to 7 weeks, with a gradual decrease from week 8 . A similar pattern of milk intake was observed by Wallgren (1944). His study of $24 \mathrm{~h}$ milk consumption in infants during the first year of life recorded maximum milk intake per $\mathrm{kg}$ body-weight from 4 to 8 weeks in male infants with a subsequent slow decline. Hofvander et al. (1982), however, in a study of seventy-five infants aged 1-3 months, recorded the maximum milk intake per kg body-weight in infants aged 1 month.

The milk yield recorded in the present paper was generally in excess of values reported in cross-sectional studies of breast-milk production. It was less, however, than breast-milk yield of Australian women reported by Rattigan et al. (1981).

It was concluded that maternal milk production during the study period was adequate to meet the nutritional needs of the infant. It is only valid to equate requirement with intake if the infant is healthy and growing within limits which are considered satisfactory. Waterlow \& Thomson (1979) have concluded that the 25th percentile body-weight of the NCHS reference (Hamil, 1977) provides a relevant standard for normal growth and that an infant's growth along this percentile (as illustrated for FJD in Fig. 1) is consistent with good health and development. 


\section{Recommended allowances for protein and energy}

Failure of the protein intake of FJD, a healthy infant with a satisfactory pattern of growth, to meet the recommended dietary allowance can be explained in terms of the now accepted revised value for the protein content of mature human milk.

Previously, the protein content of human milk was calculated on the basis of the total $\mathrm{N}$ content multiplied by the conversion factor of 6.38 and was assumed to be 11-12 g/1 (Macy \& Kelly, 1961). It is now accepted that this value overestimated the protein of human milk, as $25 \%$ of the $\mathrm{N}$ is derived from non-protein-N. Forsum \& Lonnerdal (1979), Blanc (1981) and Hambraeus (1982) have reported that the true protein content of human milk ranges between 8 and $9 \mathrm{~g} / 1$.

The protein allowance for an infant of 0.6 months, recommended by the (US) Food and Nutrition Board (1980), is derived from the 1973 recommendations of the Food and Agricultural Organization and the World Health Organization (FAO/WHO, 1973). These recommendations were based on a protein content of $11 \mathrm{~g} / 1$ in human milk. An appropriate $25 \%$ reduction in the protein allowance for an infant of 0-6 months would provide an allowance of the same order as the protein intake of the infant (FJD).

Whitehead \& Paul $(1981 b)$ have reviewed the published information on measured food energy intakes of healthy infants, shown to be growing at a satisfactory rate. These authors concluded that the energy intake of breast-fed infants frequently did not meet recommended dietary allowances and that for infants, particularly from 3 to 9 months of age, energy recommendations are probably in excess of true needs. While FJD's energy intake from 2 to 10 weeks after birth was in excess of the recommended allowance for energy (Food and Nutrition Board, 1980), the decrease in his energy intake/ $\mathrm{kg}$ body-weight from weeks 11 to 13 (which was below the recommended allowance of $480 \mathrm{~kJ} / \mathrm{kg}$ body-weight) is consistent with the previously-reported findings.

\section{Efficiency of energy conversion in lactation}

The detail of values collected in the present study permitted a calculation of the energy cost of lactation. Until recent years, authorities, both national and international, had estimated that a lactating woman required a supplement of approximately $4000 \mathrm{~kJ} / \mathrm{d}$. The efficiency with which maternal dietary energy is converted into milk energy was estimated to be approximately $60 \%$. Thomson et al. (1970), however, reviewed the available information and studied the diets of twenty-three women who were breast-feeding and thirty-two who were bottle-feeding. It was concluded that the energy exchanges in human lactation have an efficiency of $90 \%$ or more, with a lower limit of $80 \%$. These workers recommended a supplement of $2100 \mathrm{~kJ} / \mathrm{d}$ for lactation.

The following calculation of the results from the present study gives an energy conversion factor, consistent with the lower estimate of Thomson et al. (1970).

Daily energy cost of lactation $=$ daily maternal energy intake in lactation + daily energy equivalent of weight loss - daily energy intake post-lactation

$=9227+900-7400 \mathrm{~kJ}$

$=2727 \mathrm{~kJ}$.

The total energy content of breast-milk yield $0-13$ weeks post-partum is estimated as $196560 \mathrm{~kJ}$, giving a mean value for the daily energy content of breast milk of $2160 \mathrm{~kJ}$.

Efficiency of energy conversion for breast-milk production $=\frac{2160}{2727} \times 100=79 \%$. 
For the present study, the energy value of breast milk has been calculated on the basis of a fat content of $40 \mathrm{~g} / 1$ (Blanc, 1981). Other workers have suggested values generally ranging from 35 to $45 \mathrm{~g} / 1$ (Macy \& Kelly, 1961; Jonas, 1980; Hambraeus, 1982). The fat content of breast milk varies significantly during a feeding with a marked increase in fat concentration towards the end of the feeding period. It also varies diurnally, with the stage of lactation and particularly between individual mothers (Prentice et al. 1981 $a, b$ ). Because of the complexities associated with deriving a value for the fat content of breast milk and the important contribution of fat to the total energy of breast milk, the efficiency of the energy conversion for breast milk production was calculated also on the basis of fat concentrations of 35 and $45 \mathrm{~g} / \mathrm{l}$. Using these values, the efficiency of energy conversion for breast milk was estimated to be 74 and $84 \%$ respectively.

In recent years, the energy increment for lactation over the allowance for non-lactating, non-pregnant women has been reduced. The US Dietary Allowances (Food and Nutrition Board, 1980) recommended an increment for lactation of $2100 \mathrm{~kJ} / \mathrm{d}$. The increment recommended in Dietary Allowances for Use in Australia (National Health and Medical Research Council, 1979) is $2500 \mathrm{~kJ} / \mathrm{d}$

The author is deeply indebted to Charlotte Davidson, who so painstakingly and conscientiously measured her milk yield over a period of 13 weeks.

\section{REFERENCES}

Beach, E. F., Bernstein, S. S. \& Macy, I. G. (1941). Journal of Pediatrics 19, 190-200.

Blanc, B. (1981). World Review of Nutrition and Dietetics 36, 1-89.

Chilver, J. E. \& McCance, R. A. (1967). Journal of Nutrition 21, 199-205.

FAO/WHO (1973). Energy and Protein Requirements. WHO Technical Report Series No. 552. Geneva: WHO.

Food and Nutrition Board (1980). Recommended Dietary Allowances, Washington, DC: National Academy of Sciences.

Forsum, E. \& Lonnerdal, L. (1979). Pediatrics 64, 536-538.

Graham, E. R., McKenzie, H. A. \& Murphy, W. H. (1970). In Milk Proteins: Chemistry and Molecular Biology, vol. 1. p.219 [H. A. McKenzie, editor]. New York: Academic Press.

Hambraeus, L. (1982). Journal of Food and Nutrition 39, 1-13.

Hamil, P. V. (1977). NCHS Growth Curves for Children, Birth to 18 years. Publication no. (PHS) 78-1650. Hyattsville: US Department of Health, Education and Welfare.

Hofvander, Y., Hagman, U., Hillervik, C. \& Sjolin, S. (1982). Acta Paediatrica Scandinavica 71, 953-958.

Hytten, C. E. (1954). British Medical Journal i, 179-182.

Jonas, A. (1980). In Human Milk: Its Biological and Social Value, p. 51 [S. Freier and A. Erdelman, editors]. Amsterdam: Excerptamedica.

Lonnerdal, B., Forsum, E. \& Hambraeus, L. (1976). American Journal of Clinical Nutrition 29, 1127-1133.

Macy, I. G. \& Kelly, H. J. (1961). In Milk: the Mammary Gland and its Secretion, vol. II, p. 265 [S. Kon and A. Cowie, editors]. New York: Academic Press.

National Health and Medical Research Council (1979). Dietary Allowances For Use in Australia. Canberra: Australian Government Publishing Service.

Picciano, M. F., Calkins, E. J., Garrick, J. R. \& Deering, R. H. (1981). Acta Paediatrica Scandinavica 70, $189-194$.

Prentice, A., Prentice, A. M. \& Whitehead, R. G. (1981 a). British Journal of Nutrition 45, 483-494.

Prentice, A., Prentice, A. M. \& Whitehead, R. G. (1981 b). British Journal of Nutrition 45, 495-503.

Rattigan, S., Ghisalberti, A. V. \& Hartman, P. E. (1981). British Journal of Nutrition 45, 243-249.

Thomas, S. \& Corden, M. (1970). Tables of Composition of Australian Foods. Canberra: Australian Government Publishing Service.

Thomson, A. M., Hytten, F. E. \& Billewicz (1970). British Journal of Nutrition 24, 565-572.

Wallgren, A. (1944). Acta Paediatrica 32(Suppl.), 778-790.

Waterlow, J. C. \& Thomson, A. M. (1979). Lancet ii, 238-242.

Whitehead, R. G. \& Paul, A. A. (1981 a). Lancet ii, 161-163.

Whitehead, R. G. \& Paul, A. A. (1981 b). Journal of Human Nutrition 35, 339--348. 